\title{
Learned Physicians and Lay Medical Culture
}

In an oft-quoted passage from the preface to his Große Wundartzney, Paracelsus presented his medicine in opposition to the book-learning and devotion to authority of the orthodox Galenic physicians. Everywhere he went he "asked diligently, researched" including "with bone-surgeons, bath-masters, the wives of learned physicians, necromancers [...], with the alchemists, in monasteries, with the noble and the humble, with the sane and the foolish" ${ }^{614}$ Even though Paracelsus added that he was unable to learn some essential answers from these people, the passage has often been cited as evidence of his special position and his proximity to folk culture. Handsch's notes put the originality and significance of Paracelsus's statement in perspective. They show that some Galenic physicians also explored in great depth and took seriously the traditional and empirical knowledge of medical laypeople. ${ }^{615}$ Unlike Paracelsus, however, who stylized himself as a man of the people, they were loath to admit it in public.

\section{Learning from Laypeople}

Handsch documented lay medical knowledge in numerous entries. Sometimes he described popular practices and convictions in general terms. In Tyrol, he reported, women allowed leeches in lake water to attach to their bare legs, and left them there until the water turned blood-red. This was an alternative to bloody cupping. ${ }^{616}$ As a preventative against the plague, it was thought that one should eat theriac on toasted bread and then inhale the stench of a sewer with a wide-open mouth, keeping the air in one's mouth for a while; this offered protection for that day. ${ }^{617}$ To treat the "Keichen" ("wheezing") of children who screamed, struggled to breathe and turned blue in the face, the children were sometimes placed in the hollowed-out body of a freshly slaughtered ox. ${ }^{618} \mathrm{In}$

614 Paracelsus, Grosse Wundartzney (1536), preface, “empsig nach gefragt, Erforschung gehapt"; "Beinscherern, Badern, gelerter Artzeten Weibern, Schwartzkünstlern [. . .], bey den Alchimisten, bey den Clöstern, bey Edlen und Unedlen, beyn Gescheiden und Einfaltigen”.

615 For a more detailed analysis see Stolberg, Learning (2014).

616 Cod. 11183, fol. 495.

617 Cod. 11251, fol. 111r; Handsch mentioned this popular Bohemian practice of inhaling foul odours from cesspools as a preservative against the plague also in other entries (Cod. 11205, fol. 80v; Cod. 11240, fol. 145r, "bohemi ad praeservationem olfaciunt cloacam").

618 Cod. 11183, fol. 205r.

Ә Open Access. (C) 2022 Michael Stolberg, published by De Gruyter. (cc) BY-NC-ND This work is licensed under the Creative Commons Attribution-NonCommercial-NoDerivatives 4.0 International License. https://doi.org/10.1515/9783110733549-021 
Leipa, people used pimpinella powder as a fortifier, adding it to their beer soup, ${ }^{619}$ and used manus Christi as a cough remedy. ${ }^{620}$ And it was a common belief ("vulgaris opinio") that if you were suffering from a "catarrh" you were not to get your head wet or take a bath. ${ }^{621}$ Handsch also described in detail how women treated "Nabelverstürzung" - the term suggests a hidden or visible protrusion of the umbilicus, a clinical picture the physicians did not even know about. Their treatment involved running the hands from the navel toward the back and then pinching or pulling up the skin there, or pressing one's knee into the child's back in a seated position on the floor and pulling back the skin of the belly until "it" gave. ${ }^{622}$ Fever patients were generally wrapped in a blanket so that the heat of the fever would leave the body; likely what was meant here was through perspiration. ${ }^{623}$

Much more abundant still were Handsch's entries about the medicines and home remedies that some lay healers used or recommended for the prevention or treatment of various illnesses. He collected some of them, along with the remedies he owed to his fellow physicians, in his Liber experimentorum, a collection of tried and tested medicines intended for use with his own patients. ${ }^{624}$ Among them was, for example, a "surefire remedy" with which a monk treated panaritia, inflammations of the nail bed 625 and a "secret remedy" to encourage the flow of urine. ${ }^{626}$ He documented the case of a boy whose pain from bladder stones was alleviated by a lay healer who gave him an ointment that smelled of balsam and juniper. ${ }^{627}$ A fellow citizen of Leipa told Handsch that the smoke of burning absinth was a reliable remedy for headaches if it was blown into the person's mouth and ears. ${ }^{628}$ Handsch owed the recipe for a "mild purgative that could also be used in pregnant women" to the widow of a royal judge; it was a decoction of senna, licorice, sage, hyssop, and other plants. ${ }^{629}$ A female cook told him about the successful treatment of mouth sores with an electuary containing among other things honey and rust. ${ }^{630}$ The wife of a certain Weitmüller

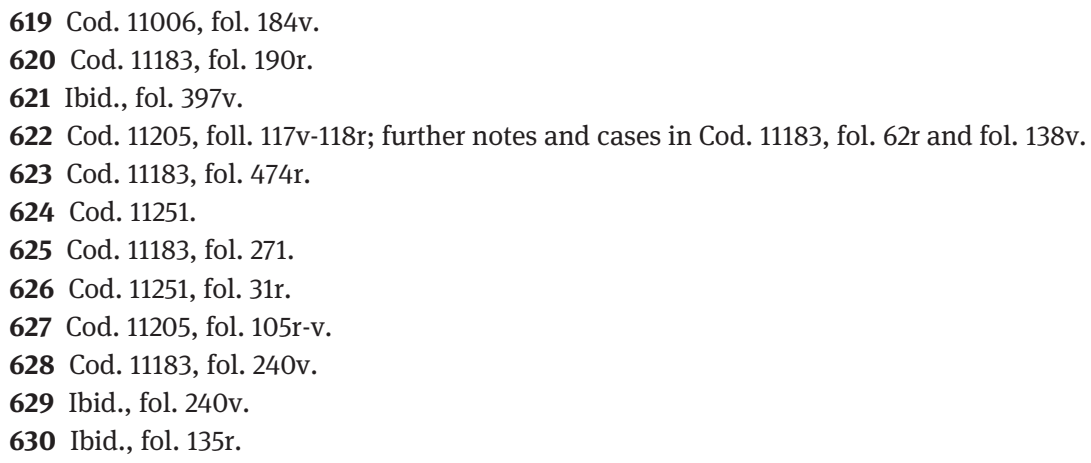


cured cold fevers with St. Benedict's thistle. ${ }^{631}$ She also told Handsch that chicory blossoms worked well for jaundice. ${ }^{632}$

In his Innsbruck years, Handsch expressed respect for the curative practice of his landlady. "My landlady knows many medicines", he wrote. ${ }^{633}$ For example, a young woman with "sciatica” came to her house asking for advice. Handsch's landlady diagnosed a "cold flux" and prescribed warm juniper oil. ${ }^{634}$ Within eight days, her treatment with St. Benedict's thistle was able to heal an ugly boil from which another patient had been suffering for years. ${ }^{635}$ Handsch also learned from her that strawberry water was good if someone felt "tight around the chest". 636

Handsch evidently took seriously the knowledge and the experiences of lay healers and even the treatment recommendations of common laypeople. In one case, he heard from a woman who had treated an ugly abscess on her leg with the leaves of a plant recommended by an old woman, and he went so far as to ask an apothecary to help him identify the plant. ${ }^{637}$ This attitude stands in striking contradiction to the aforementioned attacks on the "murderous" misdoings of the "ignorant" empirici which physicians mounted in their published writings. Only seldom do we find instances in which a learned physician publicly credited lay healers, the empirici and vetulae, with successful treatment or at least took their recommendations seriously.

Considering the growing appreciation of empirical knowledge within academic medicine, there were good reasons not to outright reject the knowledge and experience of the lay healers. After all, their curative successes were confirmed by the testimony of numerous people. They could not simply be brushed aside. Handsch was thus in good company with his respect for what he could learn from lay healers. The famous Paduan professor Vettore Trincavella stated to his students that there were "sometimes old women who achieve much with their herbal decoctions”. ${ }^{638}$ From the no less famous Gabrielle Falloppia, Handsch

\footnotetext{
631 Ibid., fol. 243v.

632 Ibid.

633 Cod. 11251, fol. 112v.

634 Ibid.

635 Cod. 11251, fol. 114v.

636 Cod. 11251, fol. 112v, "eng umb die Brust”.

637 Cod. 11183, fol. 45v.

638 Cod. 11238, fol. 88r.
} 
heard that in a severe dysentery epidemic, the physicians had tried all kinds of remedies. The most effective one, however, came from an old woman who made it from cabbage and bacon fat; within three days, the sick were well again. ${ }^{639}$ Falloppia also recommended the repeated local application of the menstrual blood of a virgin as an excellent means to reduce the size of excessively large breasts. An old woman had taught him this remedy, which, according to Falloppia, acted by its "total substance". He had experienced its effects numerous times. ${ }^{640}$ Elsewhere, too, physicians occasionally approached lay medical knowledge with a remarkably open mind, without making public knowledge of it. The English physician John Symcotts made numerous notes in his private notebook about the knowledge he gained from female lay healers who had learned from their own experience; he repeatedly documented their treatment of patients. He even learnt from a woman beggar how to make a certain remedy. ${ }^{641}$

Physicians might even resort to lay healers in their own illnesses. Handsch was told by an old court physician who suffered from dropsy. It was not hurting him very much but when he reached under his ribs on the left, he noticed something like an egg. Breathing was difficult when he climbed stairs and his belly always swelled up after eating and was smaller again in the morning. He put his trust in the arts of an old woman healer who had supposedly healed many dropsical patients before him. The old woman gave him an oil to ingest and told him to soak linen in his own urine and apply it. Instead of his own urine, the man took that of a healthy boy. After eight days, he said, his spleen was healed, though he still felt weak. ${ }^{642}$

Writing about his encounters with lay healers, Handsch sometimes even explicitly used phrases such as "I learned that" and "he taught me". For example, in one entry he noted down what the empiricus of Leipa had "taught" him about the use of antimony. Handsch had given quite a number of patients antimony, but instead of it producing many bowel movements, as he expected and hoped, vomiting occurred. The empiricus told him he had to give mastic with it,

639 Cod. 11251, fol. 30r.

640 Falloppia, Tractatus (1566), fol. 51r (based on the notes of Falloppia's student Petrus Angelus Agathus); the old woman recommended more specifically the blood from the first menstruation of a virgin.

641 Poynter/Bishop, A seventeenth-century doctor (1951), pp. 54f. and pp. 80f.; in the eighteenth century, the Nürnberg physician Götz, for example, still made the empirical medical knowledge of ordinary women his own (Kinzelbach/Neuner/Nolte, Knowledge (2016), p. 109).

642 Cod. 11205, 220v-221r; Handsch called him Dr. Michael Cadanensis; presumably, "Cadanensis" was not his name, however, but indicated his place of origin, the town of Kaaden, today's Kadaň, not far from Annaberg. 
and then he would achieve his aim. ${ }^{643}$ The empiricus also "taught" him a recipe for a purgative that was often used "in cold fluxes". ${ }^{644}$ From a miller near Innsbruck, Handsch "learned" that there was no better remedy for the "Breun" presumably an inflammation of the throat - than the juice of three crabs. ${ }^{645}$

Some lay healers furthermore possessed specialized knowledge and skills that most learned physicians could hardly claim for themselves. The production of oily essences from juniper and other plants through distillation is an example. ${ }^{646}$ Handsch praised the gentle procedure commonly used by the old women to distill rose water from petals, and he described it in detail. ${ }^{647} \mathrm{He}$ also gave an in-depth account of getting together with the empiricus in Leipa in 1558 to produce medicinal antimony. ${ }^{648}$ Finally, as we have seen, the experience and specialized skills of lay healers were valuable not least of all when it came to a disease that had not been discussed by the ancient authorities, namely the French disease. In particular, Handsch mentioned a number of Jewish healers who treated sufferers of the French disease. He watched them work and noted down what they told him. ${ }^{649}$

\section{A Shared World?}

For a long time, medical historians painted a dichotomous picture of early modern medicine. There was, one the one side, the "true" medicine, practiced by physicians, which ultimately led to modern medicine. On the other, there was "folk medicine", which was largely passed on orally and shaped significantly by "superstitious" practices. This picture fit in with the overall notion of an elite culture and a "folk culture" existing parallel and in opposition to each other in premodern society. In more recent research in social and cultural history, these dichotomies have been fundamentally challenged. ${ }^{650}$ In the course of this development, medical historians have criticized the term "folk medicine", and with it the idea

643 Ibid., foll. 122v-123r: "docuit me empiricus Lippensis."

644 Cod. 11205, fol. 519a v, "docuit me empiricus Laurentius”.

645 Cod. 11251, fol. 112r; Handsch made that note in a section devoted to the proven remedies or "experimenta" "which I learnt in Innsbruck". The German term "Bräune" usually referred to diseases of the throat with symptoms that were similar to those associated with diphtheria today.

646 Cod. 11240, fol. 132r.

647 Cod. 11205, fol. 139v.

648 Ibid., fol. 131v and fol. 132a v.

649 See the chapter on the French disease.

650 Burke, Popular culture (1979). 
that there was something like an independent medicine of the "common man" that could be seen as separate from academic medicine. ${ }^{651}$ These recent studies instead paint the picture of a pre-modern medical world that was shared by learned physicians and common folk, in which no clear dividing line could be drawn between lay medical culture and learned medicine as practiced by physicians. ${ }^{652}$

The research presented here essentially confirms this thesis of a shared medical worldview. Certainly, there were some marked differences. While empirical knowledge was becoming increasingly valued, medicine as practiced by learned physicians continued to be based in great measure on book-learning. It drew on a complex theoretical edifice shaped by the classical Hippocratic and Galenic heritage as well as by Aristotelian philosophy, and it had at its disposal a sophisticated logical and methodological apparatus. Its disease categories were far more complex than those used by laypeople. Moreover, the learned medical literature - fever theories are a good example here - described, differentiated, and explained many disease phenomena and diagnoses for which lay medicine had no terminology and no equivalents. And not least of all, with the rise of anatomy, learned physicians were increasingly able to rely on detailed knowledge about the structure of the human body. Yet, in medical practice, in everyday encounters with patients and their relatives, the commonalities, as we have seen, continued to outweigh the differences. For the majority of cases, physicians relied on a very limited number of diagnoses such as "fever", "catarrh", or "flux", "obstruction", "dropsy", or "suffocation of the womb”, all of which were familiar to laypeople. They also attributed most diseases to unclean, insufficiently concocted, rotting, or otherwise corrupted morbid matter that could be traced to a blockage or disruption of the flow of humors and the excretions; to a stomach that was either too weak, too cold, or overtaxed by food; and, more rarely, to an excessively heated liver or to a contagion that had entered the body from the outside. As physicians explained to their patients using metaphorical language that was readily graspable by laypeople, these pathogenic substances could spread throughout the blood or accumulate in certain places in the body. There, they could spoil further, harden to become tumors, or give off disease-causing vapors. Consequently, physicians as much as laypeople in most cases considered it of paramount importance for successful treatment that morbid matter be evacuated, obstructions be

651 Stolberg, Probleme (1998); Wolff, Volksmedizin (1998).

652 Nagy, Popular medicine (1988), p. 52; Gentilcore, Was there a "popular medicine" (2004) and, for France, Brockliss/Jones, Medical world (1997), esp. p. 16, have arrived at the same conclusion; looking at the situation in France around 1800, Ramsey, Professional and popular medicine (1998) still was not able to identify a clear demarcation line. 
dissolved, and weakened organs - the stomach, the heart, and/or the brain - be strengthened.

The far-reaching agreement between the physicians' conceptions and practices and those of laypeople raises the question as to why these similarities existed. A comparison with the very different medicine of non-Western cultures, such as traditional Indian or Chinese medicine, suggests that one central factor was the shared cultural heritage of laypeople and learned physicians. Many of the fundamental ideas about the origin and treatment of diseases, as well as the understanding of the therapeutic use of many medicinal plants - which, taken together, formed the basis of the medical world of the Renaissance - had been handed down from antiquity. It is quite possible, likely even, that the physicians of antiquity, in turn, already seized on images, ideas, and experiences from the lay medical culture of their day and put them into writing. In subsequent times, laypeople doubtlessly adopted concepts from learned medicine countless times. This is difficult to prove for a lay medical culture that was largely passed on orally and by way of routine practices but the popularity gained by "chemically" produced medicines in the sixteenth century among the general population, ${ }^{653}$ and the rise of the "nerves" that started in the late seventeenth century ${ }^{654}$ offer vivid proof that the premodern lay medical culture was fundamentally adaptable and open to innovation. Even the preeminent significance of uroscopy for early modern lay medical culture did not by all appearances arise from "folk medicine" but was crucially owed to the great appreciation uroscopy had enjoyed in the learned medicine of the Middle Ages.

My research into theories and explanatory models that guided everyday medical practice strongly suggests that learned Renaissance physicians, in turn, were prepared to move much closer towards the medical world of laypeople than their published polemics against the ignorance of the "vulgus" would make as believe. As Nancy Siraisi, Danielle Jacquart, Luke Demaitre, Chiara Crisciani, Joel Agrimi, and others have shown, the doctrine of "dyscrasia" or "intemperies"- that is, a disrupted balance of the four natural humors and the body's four primary qualities still enjoyed a very prominent place in medieval medicine, not just in theory but also in practice. ${ }^{655}$ Sources like consultation letters suggest that medieval physicians relied to a far greater extent on the traditional doctrine of humoral balance than physicians in the Renaissance. And as we have seen, this doctrine was still

653 Cf. Eamon, Science (1994).

654 Stolberg, Experiencing illness (2011), pp. 170-195.

655 E.g. Joel Agrimi and Chiara Crisciani, leading experts in the field of medieval medical theory and practice, have explicity characterized this concept as the dominant one (Agrimi/Crisciani, Malato (1980), p. 39). 
playing a greater role in the university lectures of the sixteenth century, which were largely based on the canon of medical literature passed down from antiquity, than on the ground, in actual medical practice. In other words, the concept of an impure, foreign morbid matter whose mobilization and evacuation was considered decisive for a successful treatment may have been old, but its towering significance in the medical practice of the sixteenth century, which by that time far surpassed that of the doctrine of dyscrasia and intemperies, was by all appearances the result of a relatively new development within learned medicine.

The humanist (re)discovery of the works by Galen, Hippocrates, and other ancient authors cannot explain this pronounced shift towards an understanding of disease which focused on unclean, rotting, corrupted, and otherwise preternatural, morbid matter, which formed and accumulated in the body due to insufficient concoction, obstructions, or disrupted excretions. The only plausible explanation for this interpretive shift, it seems to me, is that these ideas had been prevalent among the lay populace for a considerable period of time and now, during the Renaissance, were increasingly taken up by learned medicine.

This immediately raises another question: what might have led the learned physicians to give more credit in their daily practice to the disease concepts that were prevalent among laypeople and thereby devalue the traditional doctrine of humoral balance, which was the basis of learned medical theory before and supported by the great classical authorities? Answering this question will necessarily involve some degree of speculation, but I would like to propose some hypotheses.

A central factor doubtlessly was the physicians' socialization. As Peter Burke stressed in a seminal article years ago, the educated upper classes of the seventeenth and eighteenth centuries began to set themselves off from the "folk culture" of the "common people". In the sixteenth century, this "folk culture" still largely shaped everyone's mental world and everyday behavior. A growing educated elite only had additional access to a second culture, a scholarly culture that was largely grounded in antiquity. ${ }^{656}$ In our context this means that the physicians and especially the growing number of physicians from a comparatively humble social background - belonged to both worlds. For their first two decades or so, in childhood and youth, they were socialized into the "folk culture" shared by their community. Like everyone else, they thus grew up with the ideas about the body and its diseases that prevailed among the lay population and learnt to accept them as unquestioned,

656 Burke, Popular culture (1978), pp. 23-28 and, on the long-term developments, pp. 244-286. 
self-evident truths. Every day, they experienced how people in their community trusted traditional diagnostic and therapeutic practices and recovered after they took medicines or were bled, after they engaged in a sympathetic ritual or resorted to a healing charm. The critical attitude physicians expressed in their publications toward lay practices and lay healers was a result of their later academic studies and part of their professional identity. But it could hardly dislodge the physicians' ideas and images of the body and its diseases that inextricably bound them to the traditional lay medical culture - the culture they had grown up with and which had become second nature to them. ${ }^{657}$

Another reason for the physicians' openness for popular medical ideas and practices would have been the shifting constellations of power on the contemporary health market. Some time ago, in two oft-quoted contributions, the British sociologist Nicholas Jewson, drawing on British sources, formulated fundamental theses about the physician-patient relationship in the early modern period. According to Jewson, physicians treated only a small number of socially highranking patients, with whom they were involved in a relationship of patronage. Under these conditions, physicians had to accommodate most of their patients' wishes and preferences if they wanted to retain their favor and secure sufficient income for themselves. ${ }^{658}$ Jewson's theses have been justly criticized in some points. In England as on the European continent, a "relationship of patronage" between patients and their learned physicians was in no way prevalent during the time he investigated. Only very few physicians depended on the favor of a handful of patients of high standing. Even imperial and royal court physicians commonly treated sick people in the respective residential city along with the ruler and his family. As becomes evident in Handsch's notebooks, in physicians' practice journals, and in published case histories, large parts of the population at least occasionally sought the advice of a physician. In the small town of Zwickau, Hiob Finzel treated about 6,000 different patients in a period of seventeen years. ${ }^{659}$

657 Similarly, Helman, Culture (2007), p. 125, has pointed out for modern medicine that physicians remain "also part of the 'folk' world for most of their lives - both before and after graduating from medical school. Both as individuals and as members of a particular family, community, religion or social class, they bring with them a specific set of ideas, assumptions, experiences, prejudices and inherited folklore, and this can greatly influence their medical practice."

658 Jewson, Medical knowledge (1974); idem, Disappearance (1976).

659 Stolberg, A sixteenth-century physician (2019). 
Nevertheless, Jewson's theses prove helpful for an understanding of physicians' motives in accommodating the ideas and practices of laypeople. While the relationship between physicians and patients may only exceptionally be characterized as patronage, it is true that patients were in a comparatively powerful position for a simple reason: they had a choice. In larger towns and cities, a number of different physicians commonly worked parallel to one another, and even in places that could only boast a single learned practitioner, patients could usually just as well consult a barber, barber-surgeon, or one of the many lay healers, or make do with home remedies. Moreover, the number of learned physicians rose steeply in the course of the sixteenth century, and they increasingly settled in places where no physician had practiced before. At the same time, medicine turned into a profession that physicians relied on entirely to earn their bread and butter. While many physicians in the Middle Ages still counted among a small elite and were quite often able to secure their livelihood through sinecures from the church, most sixteenth-century physicians largely depended on the income from their practice to make a living. Also, most physicians no longer lived in celibacy but started families. Many of them had several mouths to feed and had to prepare to pay for the dowry of their daughters and the education of their sons. In a situation in which physicians knew that their patients could turn their backs on them at any time if they disliked their diagnosis or treatment, the incentive was great to make diagnoses, give explanations, and offer treatment methods that would satisfy the expectations and wishes of patients and relatives, and thus fall in line with their medical worldview.

Yet, why were the physicians unable to establish the traditional model of humoral balance in the world of laypeople? What made the explanation of diseases as resulting from raw, unclean, or spoiled morbid matter that needed to be evacuated from the body so attractive, to the point that physicians had to adapt the patients' way of thinking in this regard? We might want to look for an answer in Mary Douglas's famous study Purity and danger. ${ }^{660}$ Foreign or at least insufficiently concocted and assimilated morbid matter that could be found in the body and to which laypeople attributed most diseases, was "matter out of place" in the sense of Douglas's famous definition of "dirt", and therefore unclean. According to Douglas, the collective fear of dirt and uncleanliness for its part may as a rule be understood as something that expresses the fear of a border violation, of a threat to national, ethnic, or cultural identities. In this sense, Douglas Biow has interpreted the general appreciation of clean streets and squares and the measures Italian cities of the Renaissance adopted to fight the omnipresent dirt

660 Douglas, Purity and danger (1978). 
as a response to the experience of diverse border violations: the warring between the city states, increasing social mobility, changes in family structure, and the inherently transgressive outbreaks of the plague. ${ }^{661}$

However, the perception of a threat to the boundaries of a community can be found in almost any place in the world at almost any time in history. The most satisfactory explanation for the particular attraction and tenacity of the notions and images of an impure, foreign morbid matter which needed to be evacuated seems to me to be another one. It is in a broader sense a phenomenological explanation, one that involves the subjective experience of the body. We will have to exercise caution here: even the seemingly natural subjective bodily experience is culturally shaped and framed. This is vividly demonstrated by the bodily sensations - commonly described by early modern patients but no longer comprehensible to us in this way - of a rising uterus, for example, or hot vapors that found a way to rise up. ${ }^{62}$ But if we compare it to the interpretation of diseases as resulting from an imbalance of the humors and qualities the doctrine of unclean, unnatural morbid matter clearly had advantages. The intemperies of traditional humoral pathology was based on an understanding of illness as a gradual deviation from a state of balance that was construed as ideal for each individual. Disease here affected the whole body which was always at the risk of a shift away from an ideal balance and the individual constantly had to make sure to maintain and, if necessary reestablish, this balance. The explanation of illness as the result of unclean, insufficiently concocted, spoiled or otherwise exogenous substances by contrast fitted in seamlessly with an ontological conception of disease. Here, it was not the body as such that became pathologically altered but the disease was like an object, something the body "had" temporarily, something external that befell it, that possibly even literally entered it like a foreign creature. ${ }^{663}$ This also meant that it would be possible to defeat the illness once and for all by mobilizing the morbid matter and evacuating it from the body.

Individuals who lived in this period believed that they could literally experience through their senses the purifying effect of such evacuations on their own body. They felt relieved, set free, which is a sensation to which many individuals today are likely still able to relate. The black, phlegmy blood from bloodletting;

\footnotetext{
661 Biow, Culture (2006).

662 Stolberg, Experiencing illness (2011); see also the classical study by Norbert Elias on the rise of the modern "homo clausus" (Elias, Prozeß (1979)).

663 In his analysis of contemporary ego-documents, Robert Jütte has likewise found that illness was experienced as something that came from the outside and indeed frequently as an “autonomous being” (Jütte, Ärzte (1991), p. 124).
} 
the mucous, bilious matter that was evacuated through vomiting; the sometimes greenish or yellowish sputum; the unpleasant stench of sweat; the waste matter produced by the intestines; the unappetizing matter that drained from pustules and abscesses, all this underscored time and again the idea that the body by its own efforts or supported by human interventions freed itself from waste matter and then recovered in the vast majority of cases.

I would argue that no other explanatory model in the history of Western medicine corresponded so precisely and directly with subjective human experience, ${ }^{664}$ neither the ancient and medieval model of humoral balance nor the later iatrochemical and mechanistic theories, and least of all modern biomedicine. No other explanatory model appealed directly to the senses to the same degree or conveyed a sense of empowerment and control in a comparable way. Illness was something that happened to the body, an outside influence that occupied it and appeared in the form of a materially tangible agent. The body's natural, healthy core remained unaffected. If one succeeded in rendering the morbid matter harmless and evacuating it, the disease was removed and the patient was healed.

\section{Witchcraft and Magic}

We have seen, then, how physicians and laypeople shared basic assumptions about the causes and the treatment of diseases, and how physicians, by all appearances, even shifted their views towards those of laypeople. There is one important area, however, where we have to add nuance to this notion of a shared medical worldview, namely regarding magic and sympathetic healing. As we will see, even here no distinct line can be drawn between lay or "folk" medicine on the one hand and learned medicine on the other but academically trained physicians tended to take a much more skeptical attitude than laypeople.

The belief in inflicted diseases or diseases that were "laid on" somebody as a spell seems to have been very common among the population. Handsch and his colleagues encountered it time and again. Above all, diseases with rare, unusual and persistent manifestations and sexual dysfunctions raised suspicion. For example, Handsch and Mattioli saw an approximately fifty-year-old man

664 Wear, Popularized ideas (1986), p. 238, has arrived at a very similar conclusion for the seventeenth century, namely that medicine "was very close to people's perceptions and sensations of illness". As he put it, purging and bloodletting, for example, "both allowed the patient to see for himself superfluous humours being removed. If one believed that there was a mass of impurity in the body, what better for the patient than actually to see it leaving?" 
from the country who for years had been experiencing a strange fit that befell him almost every month: he would feel nauseous and have intense pain in his left thigh. He would not eat for days and stand leaning against a wall without moving a muscle or saying a word until he collapsed and fainted. During the fit, the man complained, it felt as if a wild animal was lying on top of him. He could not move but only kicked about with his feet, beset by great fear. The sick man suspected that the complaint had been inflicted on him, a maleficium, as Handsch conveyed this suspicion. His father's lover had once cast a maleficium upon his mother and he feared that it had transferred to him. ${ }^{665}$

This was not an isolated case. An impotent decan believed that a maid had cast a spell on him. ${ }^{666}$ Even a noblewoman like the Baroness of Hungerkasten wondered whether perhaps her husband's lover had cast a spell, giving her severe headaches and other complaints. ${ }^{667}$ Another noblewoman sought Willenbroch and Mattioli's help because she had been unable to sleep for eight days and was trembling. She, too, believed that the cause was a maleficium. Handsch learnt that she had had an impotent husband whom Mattioli had cured with a "remedy for maleficia" that he had found in Arnaldo de Villanova's writings. ${ }^{668}$ When a strapping young man in the service of the court was gripped by madness, people believed that a certain woman had bewitched him. ${ }^{669}$ According to Handsch's stepmother, St. John's wort (hypericum perforatum) helped women in childbed ward off diabolical maleficia. ${ }^{670}$ Even an old man who suffered from nothing more than burning when he passed water believed that this was due to a maleficium a female neighbor had cast. ${ }^{671}$

Handsch and the physicians in his professional environment did not doubt that diseases could be inflicted or that spells could be cast. Handsch took pride in a remedy he had invented to counteract a love spell that caused newlyweds, like his brother-in-law Heinrich, to become impotent: St. John’s wort, acting as a "fuga daemonum", had to be laid in the man's bed. St. John's wort also helped with Lehner's dog, which stopped barking for two weeks; now it was barking again. And it further helped with sheep who were under a spell. ${ }^{672}$

\footnotetext{
665 Cod. 11183, foll. 288r-289v.

666 Cod. 11205, fol. 256v.

667 Ibid., fol. 502r.

668 Cod. 11183, fol. 117r.

669 Ibid., fol. 478v.

670 Cod. 11205, fol. 417v.

671 Ibid., fol. 572r.

672 Ibid., fol. 406r-v and fol. 417v.
} 
The existence of demons and witches was generally recognized among educated people, and philosophers and theologians at the time were involved in a highly complex and sophisticated scholarly debate on the topic. ${ }^{673}$ This scholarly demonology borrowed elements from lay culture but ultimately built a complex theoretical edifice which served to justify torture and death sentences for alleged witches. ${ }^{674}$ Physicians, however, increasingly raised doubts. As Martin von Drembach (1500-1571) stated in 1548, it had to be conceded that demons could attack the body, but it could not be denied that the raging of atra bilis, or black bile, could cause very similar changes in melancholics. ${ }^{675}$ Johann Weyer and Thomas Erastus denied that alleged witches possessed any supernatural abilities at all, saying that they were unable by their own efforts to make people sick with a spell. Rather, the originator of these misdeeds was the devil. He was very skilled at deceiving people, making them believe that the illness in question was caused by people. Erastus nevertheless demanded punishment on the grounds that the women had after all entered a pact with the devil. ${ }^{676}$

Physicians introduced similarly subtle distinctions when it came to magical healing. The population was familiar with a broad spectrum of practices relating to sympathetic magic and folk piety. ${ }^{677}$ Handsch noted down a great number of them. People said that if bitten by a rabid dog, one had to put the dog's hair in the wound. ${ }^{678}$ From a captain he heard that wounds caused by a knife, a sword, or a nail did not fester if one thrust the weapon or the nail into a piece of bacon. ${ }^{679}$ A patient showed him an amulet that had cured his impotence. ${ }^{680}$ The town scribe of Leipa told him about a woman suffering from a fever who recovered the instant someone put an amulet with a curative slip of paper around her neck. It read: "I, Margaretha, have the cold. Thunder, lightning, and hellish fire come into me, so it will soon go away". ${ }^{681}$ A schoolmaster working for the Count of Donin was familiar with the use of the wood of gallows, accompanied

673 Cf. the magisterial study by Clark, Thinking with demons (1997).

674 Institoris, Malleus (1511); Handsch knew this work (Cod. 9666, fol. 141r; Cod. 11200, fol. 241v).

675 Drembach, De atra bile ([1548]), conclusio XX.

676 Weyer, De praestigiis (1564); Erastus, De lamiis (1578); cf. Gunnoe, Debate (2002); on Weyer see Waardt, Johann Wier (2018), with further references.

677 For a rich regional study, focussing on the Saar area see Labouvie, Verbotene Künste (1992), esp. pp. 95-110.

678 Cod. 11183, fol. 218r.

679 Cod. 11205, fol. 151r.

680 Cod. 11183, fol. 87r.

681 Cod. 11205, fol. 700v: "Ich Margaretha habe das Kalde. Donner, Pliz und hellisch Fewer komme in mich, so vergehts mich bald." 
by pious prayer, to cure diseases. ${ }^{682}$ And Handsch even thought it worthwhile to note down the exact wording of various healing charms. With fever, for example, one was to take three pieces of bread and on the first piece write "pax pater", draw a cross and say the Lord's Prayer three times, as well as three Ave Marias. On the second, one was to write "Amor. Amor filius", add two crosses, and say five Lord's Prayers and five Ave Marias, because of the Five Holy Wounds. On the third piece, one was to write "virtus spiritus sancti", say seven Lord's Prayers and seven Ave Marias, because of the seven gifts of the Holy Spirit. 683 "Black magic" as well had Handsch's attention, for example the belief that a man would became impotent if one sewed a needle into his clothing that had been used to sew a corpse into a shroud. ${ }^{684}$

Some physicians met such procedures with a certain skepticism and denounced them as "Aberglaube" or in Latin as "superstitio". ${ }^{685}$ Handsch occasionally used this term as well. For example, he wrote "superstitio" in the margin of an entry about the way some people treated fevers. He had learned that some peeled a hardboiled egg and put it in an anthill. When the egg was consumed, so too was the fever, they claimed. ${ }^{686} \mathrm{He}$ also thought it was "superstitio" when people believed that the fever would end when you had the sick person drink from the hand of a hangman. ${ }^{687}$ He used the term "Affenglaube" (the faith of apes) - a common synonym for "Aberglaube" (superstition) at the time - when he commented on the treatment of a "Nabelverstürzung" in an infant, carried out with the help of a fire poker that was held to the navel, while the following words were spoken: "Arrange yourself, stomach and navel, like this handle and the poker, in the name of etc." 688

Yet, there are also many entries in which Handsch described the successful use of magical, sympathetic procedures without taking a critical distance and without showing any doubt that patients recovered due to these procedures. He described, for example, how his four-year-old niece fell seriously ill with a fever. She coughed, vomited, and had a strong nosebleed. To stop the latter, a certain Martha - presumably a maid - tied long pieces of red yarn around the girl's knees, elbows, wrists, and several other joints. Apparently, the sympathetic effects of the color red and the "stanching" were supposed to stop the flow of

682 Cod. 11183, fol. 2r.

683 Cod. 11006, fol. 186r.

684 Cod. 11183, fol. 210r; on early modern love magic see Hacke, Wirkungsmächtigkeit (2001).

685 On the history of the concept see Grodzynski, Superstitio (1974).

686 Cod. 11183, fol. 472r.

687 Cod. 11205, fol. 469r.

688 Ibid., fol. 118r. 
blood. The hope was fulfilled: the child felt better the very next day. The nosebleed came back intermittently, but then stopped completely. ${ }^{689}$ A member of the high nobility like Sigismund von Berka was familiar with this practice as well. He sent a string of red yarn to a sick man, advising him to wrap it around his fingers and the joints of his arms. ${ }^{690}$ Twice, in two separate entries, Handsch came back to the healing effects of pepper that supposedly grew on the grave of Jaroslaw von Bernstein. Everyone in the village who was suffering from a fever had been given some of the pepper and everyone had been rid of their fever. ${ }^{691}$

Physicians were not fundamentally opposed to amulets either. Handsch declared that the classic incantation "Abracadabra”, written on a piece of paper and hung around the neck as an amulet, was an effective remedy for fevers, even if he did not think it advisable to reveal this to patients and their relatives. To avoid appearing "superstitiosus", the physician was to put the slip of paper in a fragrant apple without the patient's knowledge and put the apple around the patient's neck. ${ }^{692}$ From Gallo, Handsch heard a story about a certain Dr. Herdwig, whose tenacious quartan fever the physicians had been unable to cure. When an old woman finally advised him to use an amulet, the physicians allegedly gave their explicit permission. The following day, the febrile attacks were so severe that the sick man was ready to throw away the amulet, but then the attacks did not happen again. ${ }^{693}$ Attending to a young woman with a toothache, Gallo achieved good results when he applied another sympathetic healing procedure. Based on Gallo's notes, Handsch described the procedure in detail: the tetragrammaton was to be written on a piece of paper - this probably refers to the letters that make up the Hebrew word for "God" or to the letters I, N, R, and I - leaving a gap between each of the letters. Then one was to pound a horseshoe nail through one letter after the other until one came to the letter that made the pain subside. As long as the nail remained there, the pain would not come back. ${ }^{694}$

Confronted with such evidence that academic physicians were open to magical procedures medical historians of the past have often deplored such "backwardness". They found it difficult to understand why even famous sixteenth- and seventeenth-century authors adhered to "superstitious" ideas. In their eyes, this

689 Cod. 11183 , fol. 208v.

690 Ibid.

691 Ibid., foll. 188v-189r and fol. 240r.

692 Cod. 11200 , fol. 242v.

693 Cod. 11207, fol. 153v; elsewhere in his notes (Cod. 11205, fol. 1v) Handsch mentioned a doctor of law by the name of Andreas Herdwig in Breslau.

694 Cod. 11207, fol. 83v. 
was in contradiction to the rational medicine that ultimately gave rise to modern, science-based medicine. Taking a closer look at the medical debates of that period, however, leads us to a very different assessment. By no means was it primarily the old-fashioned physicians, the antiqui, who believed in amulets and sympathetic magical healing. On the contrary: the belief in the efficacy of magical procedures was in some respects the more modern one. It was yet another expression of the increased appreciation of empirical knowledge. It was a fundamental principle of empirically-based natural philosophy that the multifarious hidden powers and actions that appertained to natural things could only be recognized by observing effects, an idea that was developed and harnessed in the concept of magia naturalis. ${ }^{695}$ The magnet's attractive force that was as inexplicable as it was undeniable and the paralyzing power of the torpedo fish, which produces electric shocks - as we know today - were vivid and oft-quoted examples. They contradicted the Aristotelian dogma that things could only act on each other by immediate contact. So, why should one exclude the possibility that such occult forces played an important role in causing and curing diseases? A renowned seventeenth-century physician like Balthasar Timaeus von Güldenklee (1600-1667) still emphatically endorsed the numerous observations and reports by various authors on such matters, asserting that they could not be discounted as mere fiction and fables. Timaeus included examples from first-hand experience, even from his own family: his servants had quarreled with an old woman who was suspected of sorcery. Soon after, Timaeus's seven-year-old daughter developed strange symptoms; she had horrible nightmares and screamed at night. Only when the old woman was burnt as a witch did the girl's condition improve. ${ }^{696}$

With all of this in mind, it is not surprising that a leading proponent of orthodox Galenic medicine like Johannes Lange (1485-1565) also arrived at a carefully weighed judgment: amulets, "ligatures", and similar periapta - objects with healing powers that were put around the neck or attached to the body to prevent or treat sickness - could certainly be effective. This was because special hidden properties ("proprietates occultae") inhered in many substances and things due to their nature or the specific influence of the stars at the time of their creation. For example, leading authors confirmed that certain plants, like St. John's wort or the herb moly had a powerful effect on evil spirits ("malignos spiritus"), protecting the houses in which they were hung. Similarly, it was

695 On changing concepts of magic see Müller-Jahncke, Von Ficino zu Agrippa (1979); on magic and empirical evidence Dear, Meanings (2006), esp. p. 110.

696 Timaeus von Güldenklee, Casus (1691), p. 328. 
claimed, wolf dung tied to the body cured colic, and black cumin seed cured catarrh.

Lange made one important qualification: the effects had to originate from the hidden, specific, material properties of these substances. Amulets were effective because and only if certain vapors flowed from them like "atoms" ("velut atomi") into the body where they acted upon the disease. While Alexander von Tralles, Gordonius, and other, older authors might have made claims to the contrary, mere words and written characters, quotes from the Bible or demon names did not possess a curative and protective effect, no matter whether they were spoken by a conjurer or written on a slip of paper and carried on the body. The same was true of rings and seals in which, supposedly, the curative powers of stars had been harnessed. Placing one's faith in such objects, according to Lange, was superstition. ${ }^{697}$ In his disputation De amuletis, Thomas Erastus (1524-1583) arrived at a similar conclusion: to credit mere words, characters, and the like with real curative power was nothing but superstition, and contradicted reason. They lacked the principles of effect that could explain a physical change. ${ }^{698}$

Yet, under the influence of Renaissance Platonism and its appreciation of immaterial powers and influences, there were also scholarly voices who advocated against such "moderate" views. In his influential publication De triplici vita, Marsilio Ficino had ascribed a significant effect even to mere words. ${ }^{699}$ Handsch considered it noteworthy, for example, that Girolamo Cardano, based on personal experience ("propria experientia"), found that bleeding could be stanched by saying, "Blood stay inside you. Like Christ in himself", three times. ${ }^{700}$ In the sixteenth and early seventeenth centuries, physicians with a Paracelsian orientation were particularly open to these kinds of ideas.

Some physicians even saw a commercial potential. The Nuremberg physician and Paracelsian Heinrich Wolff (1520-1581) offered the physician and poet Johannes Posthius (1520-1581) and his wife two copies of a sigillum in piscibus, asking two talers apiece; this included instructions on how to use it and a de-

697 Lange, Epistolarum (1589) pp. 159-167 (= book 1, letter 34: "De physicis medicorum ligaturis \& periaptis \& anulis").

698 Published posthumously in Erastus, Disputationum (1595), foll. 95-109v, Disputatio XXII: De amuletis; on Erastus and his position on central issues in contemporary medicine see also Kühlmann/Telle (1985), pp. 265-271.

699 Ficino, De triplici vita (1498); see also Müller-Jahncke, Von Ficino zu Agrippa (1979), pp. 32-39.

700 Cod. 11200, fol. 242v: "Sanguis mane in te. Sicut Christus in se" 
scription of the illnesses against which it helped. He said that he had the sigillum produced for several gentlemen and seven copies remained. ${ }^{701}$

The majority of orthodox Galenic physicians until far into the seventeenth century appear to have had a certain faith in amulets and other curative objects attached to the body only in so far as the effects could be explained through their intrinsic, material powers. Some expressed skepticism even in this regard. They would not even accept Galen's claim that he cured an epileptic boy by hanging a peony around his neck. ${ }^{702}$ For others, amulets - in the sense of substances with proven curative powers that were hung around the neck or otherwise attached to the body - formed an important part of their therapeutic repertoire. Augustin Thoner (1567-1655) in Ulm, for example, recommended an amulet made of shiny red coral for a patient's insomnia and bad dreams. ${ }^{703}$ Numerous authors confirmed the efficacy of arsenic and mercury amulets as preventatives against the plague. ${ }^{704}$ Following in this vein, the Berlin physician Johann Georg Magnus offered the advice that one could protect oneself from the plague not only by putting incense powder on hot coals in the morning and the evening to cleanse the air and by smelling a scented sachet at noon, but also by wearing an amulet with mercury and bezoar over the heart. ${ }^{705}$

Incidentally, even critically-minded contemporaries like Weyer and Erastus conceded that magic spells and amulets containing allegedly curative words or letters sometimes seemed to produce spectacular effects. They merely explained them differently, calling them the work of the Devil, who knew how to skillfully manipulate natural things and deceive humans. The purported curative success was thus demonic and using such means was against the divine order. ${ }^{706}$

Weyer offered a further explanation, which may strike us as remarkably modern in hindsight: the healing power of amulets and charms was owed to the power of the human mind ("vis animi nostri"), that is to the sheer belief in the efficacy of these means. Faith, he claimed, could go a long way, especially with the uneducated. This was very apparent with toothaches, for which these procedures were often used. If a sick person had no faith in the treatment or even

701 Fürstlich Oettingen-Wallersteinsches Archiv Harburg, Oe.B. VII. $2^{\circ}$ 6, pp. 371f, letter from Wolff to Posthius, 24 January 1572 (www.aerztebriefe.de/id/00004767, M. Huth).

702 Letter from the Coburg physician Peter Hofmann to Sigismund Schnitzer, Coburg 13 November 1602, in: Hornung, Cista medica [1626], pp. 386f.

703 Thoner, Observationum (1649), p. 351; on Thoner see Kutzer, Herrgott (2000).

704 Letter from Sigismund Schnitzer (d. 1622) to an unnamed physician, in Hornung, Cista medica ([1626]), pp. 47-54, with numerous references.

705 Staatsbibliothek Berlin, Ms. germ. qu. 34, foll. 24r-29r, undated letter from Magnus to Sigismund von Goetze (www.aerztebriefe.de/id/00015550, S. Schlegelmilch).

706 Erastus, Disputationum (1595), foll. 95r-110v. 
thought it laughable, or if bystanders scorned it, the soothsayer ("praecantans") could do nothing. He had witnessed this in the case of a girl from the nobility, Weyer added. At first, the magic spell had relieved her toothache, but when she was reproached about it on religious grounds, the pain came back. ${ }^{707}$

The great influence of faith on the therapeutic result - today we would speak of placebo effects - was demonstrated vividly in stories like the one told again by Weyer, about a woman who was suffering from an eye complaint. She improved considerably after an amulet was placed around her neck. In the end, she was so much better that she took the amulet off. Someone opened it and found a slip of paper that, as it turned out, did not have biblical quotations written on it but the words: "May the Devil scratch your eyes out and shit in the holes". In his sarcastic comment, Weyer added that if spells like this were truly effective, the woman would have lost her eyes. ${ }^{708}$ Gallo - who, according to Handsch, ${ }^{709}$ generally thought highly of amulets - offered a similar story about an amulet that, in the judgment of physicians, could hardly have produced the good results that were attributed to it. ${ }^{710}$ The amulet seemed to have cured a girl of tertian fever. Then a man opened it, found a slip of paper with a verse from the psalms, threw it in the fire - and the fever came back. The man consoled the girl and pretended to write the verse on another piece of paper. In fact, however, he only wrote down nonsense words. The amulet with the piece of paper was put back around the girl's neck and the fever went away again. Handsch attributed what had happened to the girl to her belief in the amulet's efficacy. ${ }^{711}$ It was not the amulet that helped but the belief in it, he noted in another entry, commenting on a similar story, or perhaps even the same. ${ }^{712}$

707 Weyer, De praestigiis (1564), pp. 432-434.

708 Ibid., p. 429: "Der Teuffel kratze dir die Augen auß, scheisse dir in die Löcher”.

709 Cod. 11200, fol. 241v.

710 Cod. 11207, fol. 154r.

711 Cod. 9671, foll. 122v-123r, "fixa fides est quae sanat interdum”.

712 Cod. 11207, fol. 154v: "Quod signum est, amuleta non conferre sed fidem." 